\title{
マクロダイバーシティ受信システムの開発と移動中継番組で の運用
}

\author{
Development of Macrodiversity Reception System and Its Use in Mobile \\ Relay Broadcast Program
}

\author{
学生会員 光 山 和 彦 ${ }^{\dagger \dagger}$, \\ 村上文弘柿，正会員 池田哲 臣
}

Kazuhiko Mitsuyama ${ }^{\dagger, \dagger \dagger}$, Fumihiro Murakami ${ }^{\dagger \dagger \dagger}$ and Tetsuomi Ikeda ${ }^{\dagger}$

\begin{abstract}
We are conducting research on a wireless link system that is capable of achieving high link reliability over a wide area for use in mobile relay broadcast programs such as road races. For such systems to be feasible, we developed a macrodiversity reception system using many distributed remote antennas and radio-over-fiber links. Our receiver combines four diversity branches with good signal quality based on the minimum mean square error (MMSE) algorithm. We describe the MMSE weight vector calculation using fixed-point operation for hardware implementation, prototyping of a macrodiversity receiver, and its use in an actual mobile relay broadcast program. Our system was used as a terrestrial reception system of high-definition videos shot from a motorcycle in the Kyoto Ekiden relay race, and achieved highly stable transmission without outage for half the course.
\end{abstract}

キーワード：マクロダイバーシティ，OFDM-FPU，MMSE，ロードレース中継

\section{1. ま え がき}

マラソンや駅伝などの移動中継では，伝搬損失が小さく， 見通し外環境であっても反射波や回折波により受信電力を 確保できる $700 \mathrm{MHz}$ 帯 OFDM-FPU (Orthogonal Frequency Division Multiplexing-Field Pick-up Unit) 1) 3) が用いられる。一方, 臨場感のあるカメラバイクのハイビ ジョン映像を無線伝送するため, 6〜 7 GHz の SHF（Super

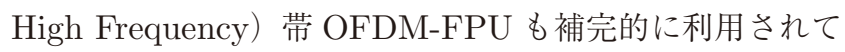
いる. SHF 带送信機は, ARIB 規格 ${ }^{1)}$ により, 隣接チャン ネルで従来のアナログ方式による運用がなされていない場 合は最大 $5 \mathrm{~W}$ まで出力が可能である.しかし, その場合で も放送事業者間での運用調整が事前に必要となり，5W出 力できる送信機のサイズ, 重量や消費電力も増大するため,

2012 年 2 月 25 日, 放送技術研究会で一部発表

2012 年 10 月 1 日受付, 2012 年 10 月 18 日採録

$\dagger$ NHK 放送技術研究所

( ₹ 157-8510 東京都世田谷区砧 1-10-11，TEL：03-5494-3462) ††慶應義塾大学理工学部情報工学科

（₹ 223-8522 横浜市港北区日吉 3-14-1, TEL: 045-563-1151) †† NHK 大阪放送局

（ T 540-8501 大阪市中央区大手前 4-1-20, TEL: 06-6937-3158)

$\dagger$ Science and Technical Research Laboratories, NHK

(1-10-11, Kinuta, Setagaya-ku, Tokyo, 157-8510, Japan)

$\dagger \dagger$ Information and Computer Science, Keio University

(3-14-1, Hiyoshi, Kohoku-ku, Yokohama, 223-8522, Japan)

$\dagger \dagger \dagger$ Osaka Broadcasting Station, NHK

(4-1-20, Otemae, Chuo-ku, Osaka, 540-8501, Japan)
いつでもどこでも使用できる条件として, 出力電力は比較 的小さくなるが，運用調整が不要な最大出力 $200 \mathrm{~mW}$ 運用することが一般的である。また，SHF 帯の電波は 700 $\mathrm{MHz}$ 帯と比べて伝搬損失も大きいことから，カメラバイク のハイビジョン映像の無線伝送は，主に見通しを確保して ヘリコプターで中継する運用形態がとられている。ただし， 天候などでへリコプターを使用できない場合や，高架橋な どによる遮蔽で伝送できない場合がある。そのため，700 $\mathrm{MHz}$ 帯と同様に，地上に設置した基地局で受信する中継形 態が望まれていたが，実運用が可能なシステムは実現され ていなかった。広範囲にわたる移動中継を実現するシステ ムとして，各基地局で受信した信号を，中継本部であるス イッチングセンターに設置された OFDM-FPU 受信装置で 復調し，復調後の TS（Transport Stream）信号を TS ス イッチャで自動的に切り替える，いわゆる選択ダイバーシ

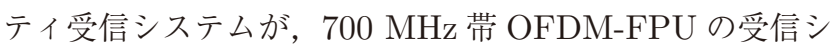
ステムとして開発されている ${ }^{4)}$. しかし，伝搬損失の大き いSHF 带を用いた場合，隣接する受信基地局のエリア境 界などで途切れやすくなるという課題があった.

筆者らは，SHF 带による地上伝送システムを実現させる ため，既存の OFDM-FPUの前段に挿入して使用するだ けで, 地理的に離れた複数基地局の受信信号を, ダイバー シティ合成できるマクロダイバーシティ受信装置を試作し た. 本装置は，最大 16 ブランチの受信信号から受信 CNR 
(Carrier-to-noise ratio）の大きい 4 ブランチを自動選択 して MMSE (Minimum Mean Square Error) アルゴリ ズムで合成する。無線伝送路あるいは光ファイバなど，有 線伝送路の経路長差に起因する信号の遅延時間差をリアル タイムに補正する機能 5)をもつため，基地局の区別なく最 適な信号を選択して合成することができる。そのため，マ イクロダイバーシティ効果 ${ }^{6)} て ゙$ 瞬時変動に対する受信特性

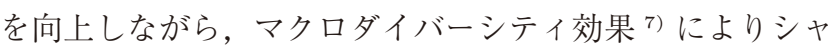
ドウイングや距離減衰による信号品質の劣化を補償し, 伝 送エリアを拡大することが可能となる。

試作した装置は，ダイバーシティ合成した信号を再変調 して出力し, 既存の OFDM-FPUへ入力する構成で使用 されるため，本装置を経由することで生じる信号の劣化が 極力小さくなるよう内部演算回路の設計を最適化する必要 がある。また，実運用を考慮した場合，本装置を経由する ことにより発生する処理遅延が，無視できる程度に充分小 さい遅延で実現できるか評価することも求められる。そこ で本論文では, 内部演算回路の固定小数点演算部の設計と, その設計に基づく装置試作と受信特性の評価について述べ る。また，マクロダイバーシティ受信装置を実際の中継番 組で運用するために必要な周辺装置と，本装置を移動中継 番組で運用した結果についても報告する。

以下 2 章では, マクロダイバーシティ受信装置の試作に 関し，MMSEアルゴリズムをハードウェア実装するために 必要な逆行列の演算方法, 信号劣化を生じさせずビット精 度を維持したまま，固定小数点演算を実現するための最適 語長の決定方法や, 決定した最適語長に基づき試作したマ クロダイバーシティ受信装置の基本特性を室内実験で評価 した結果を説明する，3 章では，本受信装置の中継番組へ の導入を容易にするための周辺設備として，新たに試作し た小型受信高周波部と IF (Intermediate Frequency) 帯 5 波 WDM（Wavelength Division Multiplexing）伝送装置 で構成される RoF (Radio over Fiber) システムについて 説明する。また，本受信装置を実際の京都駅伝中継番組で 使用し，カメラバイクから SHF 帯の電波を用いて送信さ れたハイビジョン映像を，全コースの約半分となる延べ 20 $\mathrm{km}$ にわたり途切れずに受信することに成功した結果を報 告する. 最後に 4 章にて本論文をまとめる.

\section{2. マクロダイバーシティ受信装置}

\section{1 概 要}

番組中継用無線伝送システムは，今後 MIMO 技術の導 入も検討されていることから ${ }^{8)}$, マクロダイバーシティ 受信装置の信号合成アルゴリズムとして, OFDM 信号の 受信と MIMO-OFDM (Multiple-Input Multiple-Output OFDM）信号の受信に共用できる MMSEアルゴリズム ${ }^{9110)}$ を使用した，MMSEアルゴリズムは，干渉波がない環境で は最大比合成として，干渉波が存在する環境では干渉を除 去する空間フィルタとして動作することが知られている。

\subsection{MMSE アルゴリズム}

送信信号と受信信号ベクトルをそれぞれ $\mathrm{x} \in \mathbb{C}, \mathrm{y} \in$ $\mathbb{C}^{M \times 1}$ ，チャネルベクトルを $\mathbf{h} \in \mathbb{C}^{M \times 1}$ としたときの伝送 路は次式で表される。ただし， $M$ は受信アンテナ数である.

$$
\mathbf{y}=\mathbf{h x}+\mathbf{n}
$$

$\mathbf{n} \in \mathbb{C}^{M \times 1}$ はノイズベクトルであり, 各要素は平均 0 , 分 散 $\sigma^{2}$ の i.i.d. 複素ガウス雑音である. MMSE アルゴリズ ムに基づいて得られる MMSE ウェイト $\mathbf{w} \in \mathbb{C}^{M \times 1}$ を次式 に示す ${ }^{11)}$.

$$
\mathbf{w}=\left(\mathbf{h} \mathbf{h}^{H}+\frac{\mathbf{I}}{S N R}\right)^{-1} \mathbf{h}
$$

ここで, $S N R$ は平均受信 $\mathrm{SN}$ 比を, $\mathbf{I}$ は $M$ 次の単位行列 を，添え字 $H$ は複素共役転置を表す．MMSE 基準による 合成出力信号 $\mathrm{z} \in \mathbb{C}$ は次式で与えられる.

$$
\mathrm{z}=\mathbf{w}^{H} \mathbf{y}
$$

試作するマクロダイバーシティ受信装置は，4 ブランチを 選択して合成することを想定しているため， $M=4$ である.

\section{3 ハードウェア実装のための逆行列演算}

MMSE ウェイト算出式 $(2)$ には， $M$ 次正方行列の逆行 列演算が含まれる。逆行列演算手法として，ガウスの消去 法や LU 分解などが一般的に知られており， $n$ 次正方行列 では $n$ が大きいときにいずれも $O\left(n^{3}\right)$ 程度の演算量が要求 される。ただし，前者では丸め誤差を避けるため，適切な 枢軸を選択する必要があり，後者では行列の分解が必要に なるなど，固定小数点演算によるハードウェア実装を行う 際のアルゴリズムが複雑となる。また，複素数を要素とす る行列を扱う場合，演算量の多い複素除算が多数発生する ほか，ゼロ除算により正確な逆行列を算出できない可能性 もある. 文献 12) では，行基本変形に基づいた $4 \times 4$ 逆行列 演算回路の実装について述べているが，複素除算に起因す る誤差を避けるため, 固定小数点演算ではなく浮動小数点 演算を用いている。

一方，余因子行列と行列式を用いる逆行列の公式は， $n$ 次正方行列で $O\left(n^{3} n !\right)$ 程度の演算量が必要であり，高次の 逆行列演算には適していない。ただし，ハードウェア実装 を考慮した場合，逆行列が解析式で事前に正確に与えられ るため，複雑なアルゴリズムが不要であることや，演算過 程で誤差増大の要因となる除算が行列式の逆数を算出する 1 回だけで済むこと，特に相関行列などのエルミート行列 は行列式が実数となることなど演算量とは異なる利点もあ る。以上の理由から，ウェイト算出回路を， $4 \times 4$ 逆行列演 算の公式を利用して実装することを試みる。

逆行列を余因子行列と行列式を用いて導出する場合, 式 (4) に示す $n$ 次正方行列 $\mathbf{A}_{n}$ の逆行列 $\mathbf{A}_{n}^{-1}$ は式 (5) で表さ れる。 


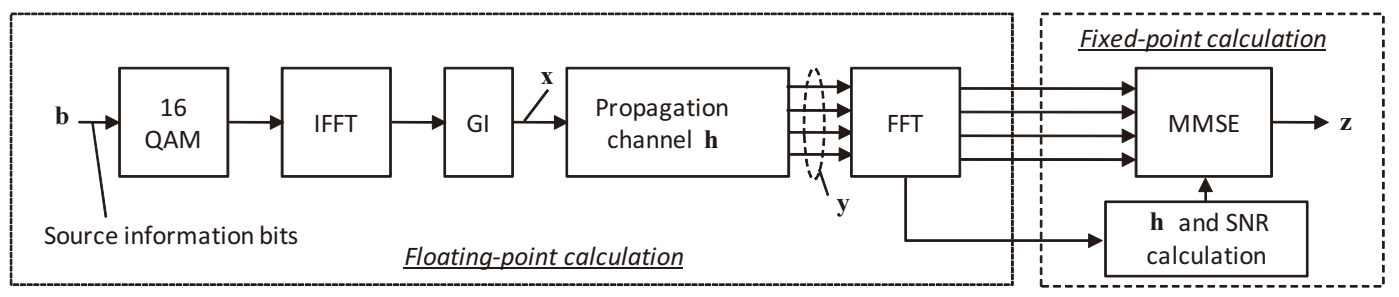

図 1 固定小数点演算検証シミュレーションブロック図 Block diagram of fixed-point simulation.

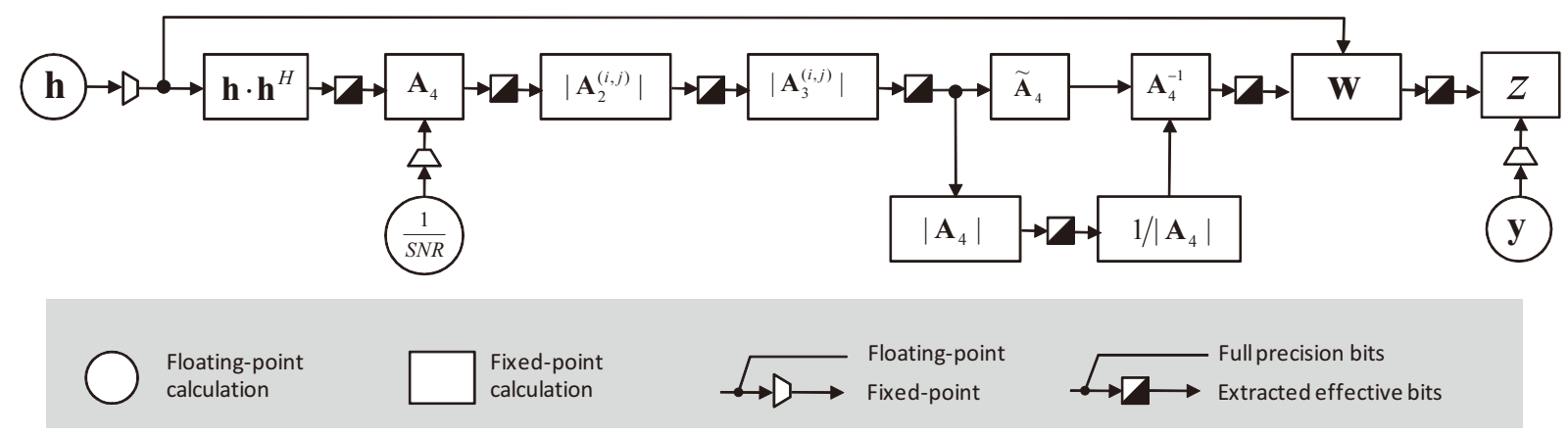

図 2 MMSE ウエイト算出部の固定小数点演算ブロック図 Block diagram of fixed-point calculation on MMSE weight vector.

$\mathbf{A}_{n}=\left(\begin{array}{rrrr}a_{11} & a_{12} & \cdots & a_{1 n} \\ a_{21} & a_{22} & \cdots & a_{2 n} \\ \vdots & \vdots & \ddots & \vdots \\ a_{n 1} & a_{n 2} & \cdots & a_{n n}\end{array}\right)$

$$
\mathbf{A}_{n}^{-1}=\frac{\widetilde{\mathbf{A}}_{n}^{T}}{\left|\mathbf{A}_{n}\right|}
$$

ここで, $\widetilde{\mathbf{A}}_{n}$ は行列 $\mathbf{A}_{n}$ の余因子行列, 記号 $|\cdot|$ は行列式, 添え字 $T$ は行列の転置を表す. 余因子行列 $\widetilde{\mathbf{A}}_{n}$ の第 $i$ 行第 $j$ 列の要素 $\tilde{a}_{i j}$ は行列 $\mathbf{A}_{n}$ の要素 $a_{i j}$ の余因子であり, $\mathbf{A}_{n}$ の第 $i$ 行と第 $j$ 列を除いた $n-1$ 次正方行列を $\mathbf{A}_{n-1}^{(i, k)}$ とす ると, 次式で表される.

$$
\tilde{a}_{i j}=(-1)^{i+j} \cdot\left|\mathbf{A}_{n-1}^{(i, j)}\right|
$$

一方, 行列式 $\left|\mathbf{A}_{n}\right|$ は, $\mathbf{A}_{n}$ の第 $i$ 行に関する余因子展開に より次式で与えられる。

$$
\begin{aligned}
\left|\mathbf{A}_{n}\right| & =a_{i 1} \cdot \tilde{a}_{i 1}+a_{i 2} \cdot \tilde{a}_{i 2}+\cdots+a_{i n} \cdot \tilde{a}_{i n} \\
& =\sum_{k=1}^{n} a_{i k} \cdot \tilde{a}_{i k} \\
& =\sum_{k=1}^{n}(-1)^{i+k} \cdot a_{i k} \cdot\left|\mathbf{A}_{n-1}^{(i, k)}\right|
\end{aligned}
$$

$\left|\mathbf{A}_{n-1}^{(i, k)}\right|$ は $\left|\mathbf{A}_{n}\right|$ に対して行列の次数で 1 だけ小さい. 2 次 正方行列または 3 次正方行列の行列式は Sarrus の公式 13) で容易に算出できるため, $n$ 次の行列式も式 (7) を用いた展 開式により算出可能である。また，式 (6)により余因子を 算出する場合, 式 (7) と共通する行列式を用いるため, 算 出順序を工夫することで逆行列演算の計算規模を削減する ことも可能である.

\section{4 固定小数点演算}

MMSE ウェイト算出部における固定小数点演算の最適 語長を計算機シミュレーションにより検証する。図 1 に MMSE ウェイト算出部の固定小数点化を検証するためのシ ミュレーションブロック図を示す。送信側では，情報ビッ 卜列 b を 16QAM 変調し, IFFT (Inverse Fast Fourier Transform）演算とガードインターバル（GI：Guard Interval）の付加を行い, 送信信号 $\mathrm{x}$ を生成する。送信信号に 対し, 後述する評価モデルに従う伝搬チャネル $\mathbf{h}$ を掛けて 受信信号 $\mathbf{y}$ を生成する。受信側では FFT 演算, チャネル 推定, MMSE ウェイト算出・乗算により信号 $\mathrm{z}$ が検出され る. MMSE ウェイト算出部の固定小数点設計のため, 図 1 に示す FFT 演算までは浮動小数点演算で行い, FFT 演算 後段の処理を順次上位側から固定小数点化するものとする.

ここでは， 4 次正方行列 $(n=4)$ の逆行列を 2.3 節に示 した方法を用いて算出し，MMSEウェイト演算を固定小 数点化した場合の中間演算における各内部变数の最適語長 の決定を，評価モデル a（1 ブランチ入力, 2 波マルチパス， $\mathrm{DUR}=0 \mathrm{~dB}, \Delta \tau=2 \mu \mathrm{s})$ と評価モデル b（4 ブランチ入力， 2 波マルチパス, $\mathrm{DUR}=0 \mathrm{~dB}, \Delta \tau=2 \mu \mathrm{s})$ を用いて行う. ここで，DURは主波と遅延波の信号電力比， $\Delta \tau$ は主波に 対する遅延波の相対的な遅延時間を表す。評価モデル a で は 1 ブランチを除いたその他のブランチは無信号, 評価モ デル b は 4 ブランチすべてに信号が入力されるモデルであ る。また， $\mathrm{DUR}=0 \mathrm{~dB}$ は，サブキャリヤ間のレベル差が 最大となり, 中間演算の各内部変数に必要とされるダイナ ミックレンジが最大となることから，最適語長検証用のモ デルとして用いた。逆行列を算出する行列を次式のように $\mathbf{A}_{4}$ で表す。 


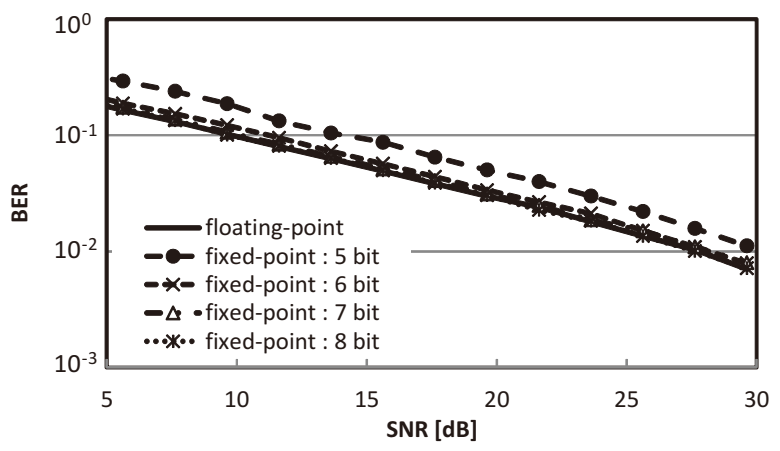

図 3 h の固定小数点化（評価モデル b )

Fixed-point calculation of $\mathbf{h}$ (evaluation model: b).

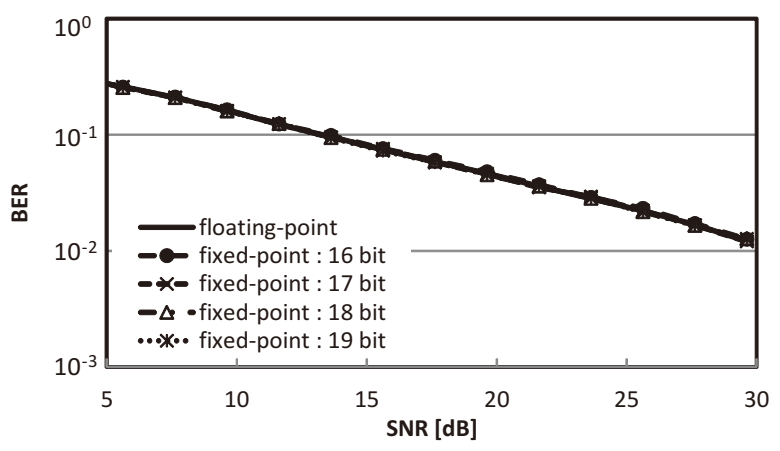

図 $4\left|\mathbf{A}_{2}^{(i, j)}\right|$ の固定小数点化 (評価モデル a )

Fixed-point calculation of $\left|\mathbf{A}_{2}^{(i, j)}\right|$ (evaluation model: a).

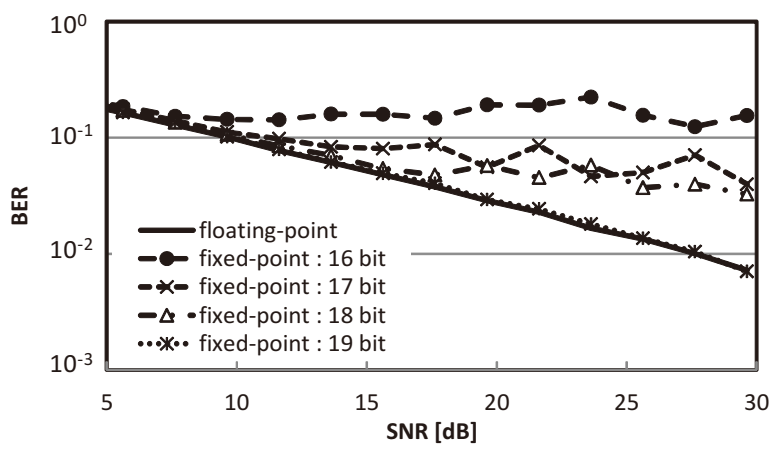

図 $5\left|\mathbf{A}_{2}^{(i, j)}\right|$ の固定小数点化 (評価モデル b )

Fixed-point calculation of $\left|\mathbf{A}_{2}^{(i, j)}\right|$ (evaluation model: b).

$$
\mathbf{A}_{4}=\left(\mathbf{h h}^{H}+\frac{\mathbf{I}}{S N R}\right)
$$

$\mathbf{A}_{4}^{-1}$ を算出し，信号 $\mathrm{z}$ を検出するまでの固定小数点演算処 理ブロックを図 2 に示す。演算の上位であるチャネルベク トル $\mathbf{h}$ から, 各内部変数の固定小数点化を順次行い, 各々 の最適語長を決定する。ここで最適語長とは，すべての処 理ブロックを浮動小数点演算で行った場合の受信特性と比 較して，特性劣化が充分小さいと判断できる最小語長であ るものと定義する. 最適語長を決める具体的な手順として, まずオーバフローを生じない小数点位置を決定して固定し た後，最下位ビット (LSB : Least Significant Bit) 側から 語長を増減させて，小数点以下の有効ビット数が異なる場 合のビット誤り率（BER：Bit Error Rate）特性を評価す るものとした.

まず，評価モデル b においてチャネルベクトル h だけを

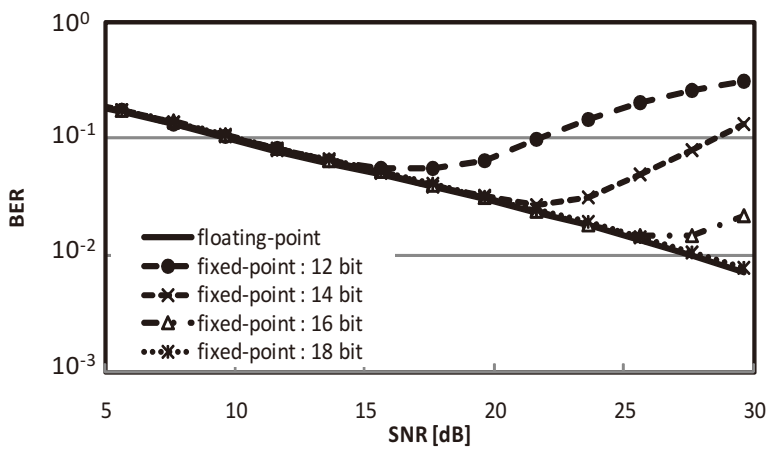

図 $6 \quad \mathbf{A}_{4}^{-1}$ の固定小数点化 (評価モデル b ) Fixed-point calculation of $\mathbf{A}_{4}^{-1}$ (evaluation model: b).

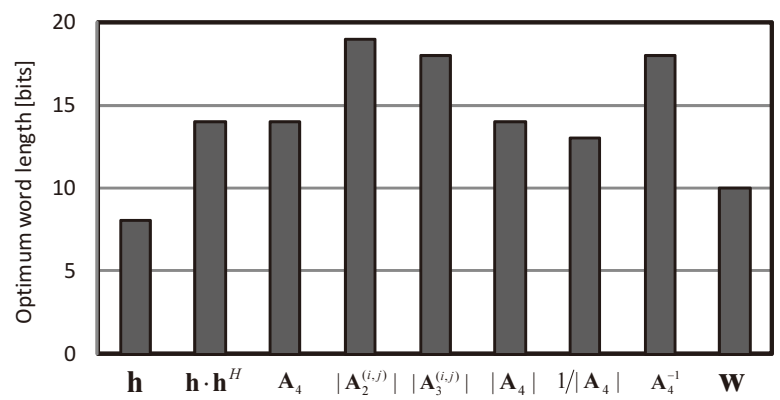

図 7 各演算部の最適語長

Optimum word length of each arithmetic logical unit.

固定小数点化した場合の BER 特性を図 3 に示す。図 3 よ り, 8 ビット程度の語長で浮動小数点演算とほぼ同等の特 性が得られていることがわかる。

次に, 行列式 $\left|\mathbf{A}_{2}^{(i, j)}\right|$ の固定小数点化に関し, 評価モデ ル a と評価モデル b を用いた結果を図 4 と図 5 にそれぞれ 示す. 図 4 より, 評価モデル a の 1 受信では 16 ビットで浮 動小数点演算と同様の特性が得られるが，図 5 に示す評価 モデル b の 4 受信では 19 ビット必要であることが確認で きる。これは信号が入力されるアンテナ数の増大とともに, $\left|\mathbf{A}_{2}^{(i, j)}\right|$ が取り得る值の範囲も増大することを示している. さらに評価モデル b において， $\mathbf{A}_{4}^{-1}$ を固定小数点化し た場合の BER 特性を図 6 に示す。図 6 から最適語長は 18 ビットであることがわかる。

最後に, MMSEウェイト算出までの各演算部の最適語長 の検証結果を図 7 にまとめて示す.

\section{5 ハードウェア試作}

最大 16 か所の基地局で受信した信号を入力できるマク ロダイバーシティ受信装置の機能ブロックを図 8 に，外観 を図 9 にそれぞれ示す。各基地局で受信された信号は，130 $\mathrm{MHz}$ 帯の IF 信号でマクロダイバーシティ受信装置へ入力 される. 入力信号は, 内部で中心周波数が約 $20 \mathrm{MHz}$ の IF 信号に変換された後，A/D (Analog-to-digital) 変換器に よりディジタル化される。直交復調, 同期検出, シンボル タイミングを合わせる遅延補正 1 までは入力系統毎に処理 が行われ, シンボル単位でパラレル/シリアル $(\mathrm{P} / \mathrm{S})$ 変換 された信号が FFT 演算部に入力される。シンボル単位の $\mathrm{P} / \mathrm{S}$ 変換と 4 倍速の動作クロックにより, FFT 演算回路規 


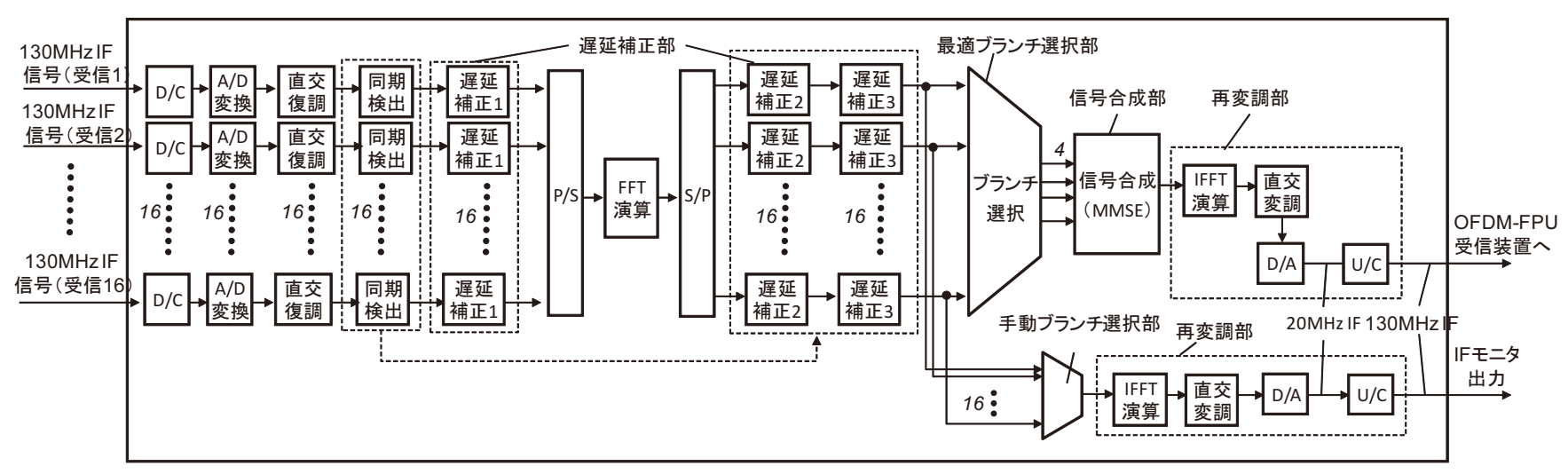

図 8 マクロダイバーシティ受信装置の機能ブロック Block diagram of macrodiversity receiver.

模の削減が可能である. FFT 演算後はシリアル/パラレル $(\mathrm{S} / \mathrm{P})$ 変換により再び入力系統毎の信号に分けられ，ブラ ンチ間のフレームタイミングを合わせる遅延補正 2 と, 最 も遅延した信号が後から入力される場合に生じる不連続を 回避するための遅延補正 3 の処理が行われ，全ブランチ間 で遅延時間差が完全に補正される ${ }^{5)}$ 。遅延補正 1 は最大 1 シンボル長, 遅延補正 2 と遅延補正 3 は最大 10 シンボル 長の信号をバッファできるメモリーを使用した。自由空間 伝搬路における距離に換算して，ブランチ間で最大約 160 $\mathrm{km}$ の経路長差に相当する遅延時間差を補正することが可 能である。

次段の最適ブランチ選択部は，16 系統の信号から CNR の大きい順に 4 ブランチを選択し，信号合成部は選択した 4 ブランチを， 2.3 節と 2.4 節で検討した結果に基づいて 実装した MMSE アルゴリズムに従い最適合成する，再変 調部は合成後の信号に対し, IFFT 演算, 直交変調処理を 行い, D/A (Digital-to-analog) 変換後に周波数変換して 図 9 に示す既存の OFDM-FPUへ入力できる $130 \mathrm{MHz}$ IF 信号を出力する. OFDM-FPUの前段に挿入して使用する ことで，コンスタレーションや MER（Modulation Error Ratio）など従来の OFDM-FPU の監視機能をそのまま活 用できるメリットがある。ただし，信号が一度マクロダイ バーシティ受信装置を経由することによる処理遅延の増大 と受信特性の劣化を評価する必要がある。表 1 に, 図 8 に おける各機能ブロックの処理遅延を時間に換算して示す.動 的な遅延補正により，マクロダイバーシティ受信装置を経 由することで生じるトータルの遅延時間は必ずしも一定で はなく, $340 \mu \mathrm{s}$ から $1520 \mu \mathrm{s}$ の範囲となる. OFDM-FPU で使用する時間インタリーブ長が約 $75 \mathrm{~ms} \sim 400 \mathrm{~ms}$ である ことから，運用上無視できる程度に充分小さい遅延時間で 実装可能であることを確認できる。マクロダイバーシティ 受信装置を経由することで生じる受信特性の劣化について は次節で詳細に評価する。

試作した装置には，実運用を考慮して，入力 IF 信号レベ ルを確認する LED 表示機能，手動で合成する信号を選択す る機能のほか, 自動あるいは手動で選択した信号をスルー

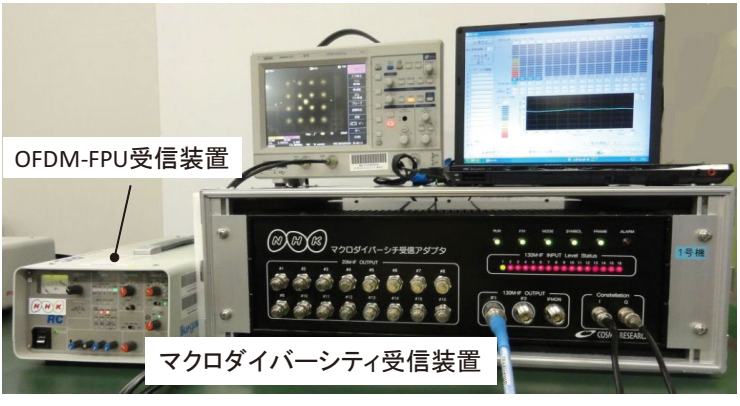

図 9 試作したマクロダイバーシテイ受信装置 Prototype macrodiversity receiver.

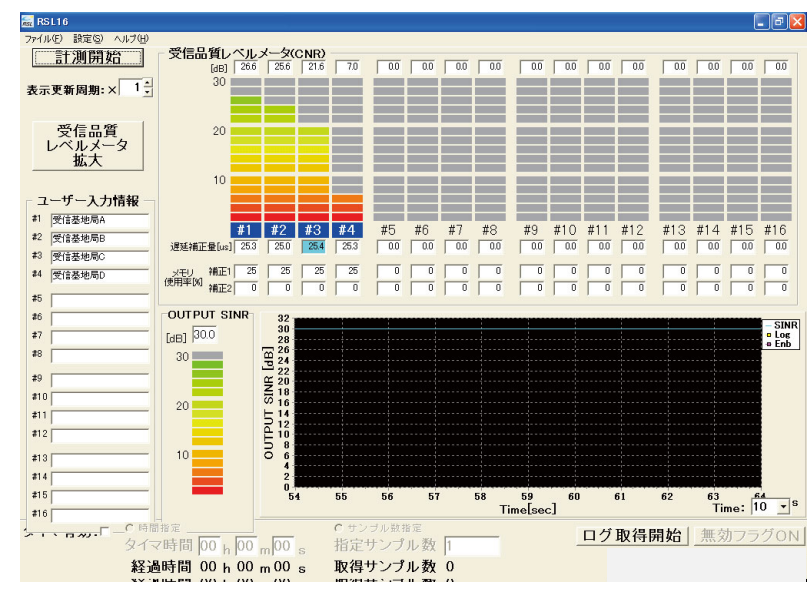

図 10 受信品質監視ソフトウェア

Monitoring software of received signal quality.

表 1 各機能ブロックの処理遅延

Processing delay time of each functional block.

\begin{tabular}{l|l|l|l}
\hline \hline 処理ブロック & 処理遅延 $[\mu \mathrm{s}]$ & 処理ブロック & 処理遅延 $[\mu \mathrm{s}]$ \\
\hline \hline $\mathrm{D} / \mathrm{C}$ & 0.70 & $\mathrm{~A} / \mathrm{D}$ & 0.06 \\
\hline 直交復調 & 1.03 & 同期検出 & 0.07 \\
\hline 遅延補正 1 (min.) & 0.29 & 遅延補正 1 (max.) & 56.57 \\
\hline $\mathrm{P} / \mathrm{S}, \mathrm{FFT}, \mathrm{S} / \mathrm{P}$ & 139.31 & チャネル推定 & 58.73 \\
\hline 遅延補正 2 (min.) & 2.64 & 遅延補正 2 (max.) & 565.95 \\
\hline 遅延補正 3 (min.) & 0.24 & 遅延補正 3 (max.) & 563.55 \\
\hline ブランチ選択 & 0.24 & 信号合成 (MMSE) & 2.02 \\
\hline IFFT & 128.08 & 直交変調 & 1.93 \\
\hline $\mathrm{D} / \mathrm{A}$ & 0.04 & $\mathrm{U} / \mathrm{C}$ & 0.7 \\
\hline
\end{tabular}

出力する機能も搭載しており, 基地局毎の受信品質を確認す る場合に有用である。また，本装置の制御や信号品質の監視 


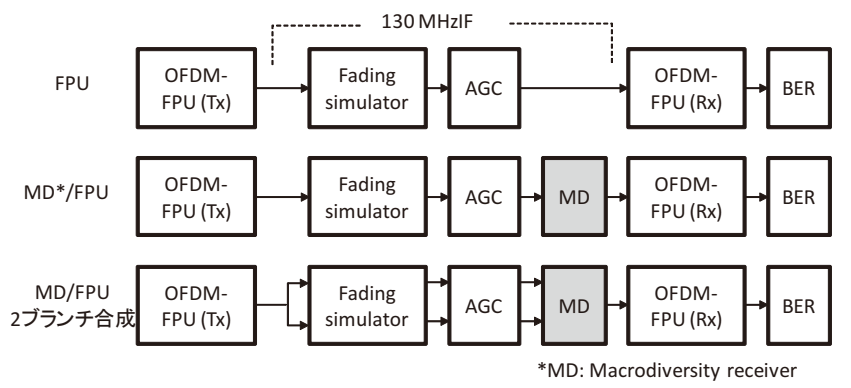

図 11 室内評価実験系統図

Schematic structure of indoor experiment.

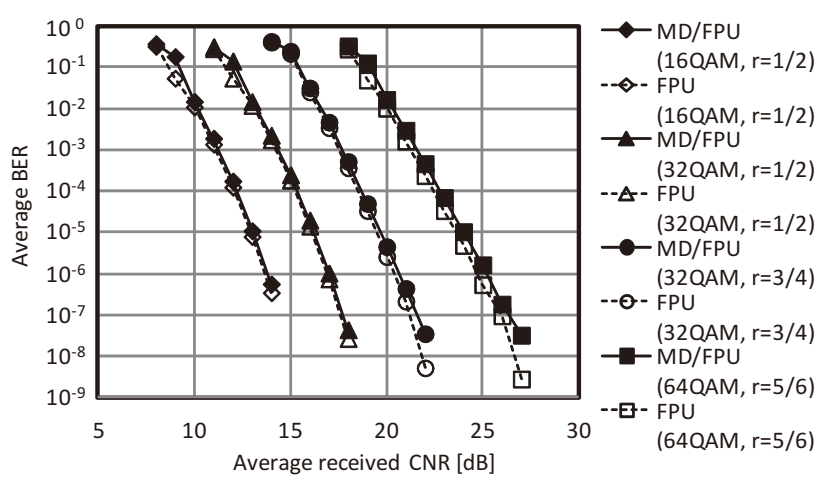

図 12 AWGN 環境におけるビット誤り率特性 Bit error rate performance in AWGN channel model.

は，図 10 に示すLAN ケーブルで接続された PC 上の GUI で行うことが可能である。また，入力系統毎の受信 CNR と信号合成後の出力 CNR, 遅延補正処理部における遅延補 正量や選択したブランチなどのロギング機能も有する。こ こで, 出力 CNR は, DBPSK 変調された TMCC (Transmission and Multiplexing Configuration Control) キャ リア ${ }^{1)}$ の複素信号值のばらつきから近似的に求めるものと した。

\section{6 室内評価実験}

試作装置の受信特性を室内実験で評価した。図 11 に実 験系統図を示す。信号源は ARIB 規格 ${ }^{1)}$ に基づく OFDMFPU 送信装置とし，フェージングシミュレータを介して OFDM-FPU 単体で受信する構成（FPU），OFDM-FPU の前段にマクロダイバーシテイ受信装置を挿入する構成 (MD/FPU) と, 同構成に扔いてマクロダイバーシテイ受信 装置で 2 系統の信号を受信する構成（MD/FPU 2 ブランチ 合成）を比較評価するものとした。フェージングシミュレー 夕は，静的な伝搬環境として，AWGN (Additive White Gaussian Noise）環境と, サブキャリヤ間のレベル差が増 大する 2 波マルチパス環境（ $\mathrm{DUR}=3 \mathrm{~dB}, \Delta \tau=2 \mu \mathrm{s} ）$, 動 的な伝搬環境として，1波レイリーフェージング環境（最 大ドップラー周波数 $\left.f_{D}=200 \mathrm{~Hz}\right)$ の 3 種類の伝搬チャネ ルを発生させた，MD/FPUの 2 ブランチ合成による測定 は 1 波レイリーフェージング環境で行い，2 ブランチ間の 受信相関は 0 とした。なお，実験ではビ夕ビ復号後の BER 特性をそれぞれ測定して比較評価した。

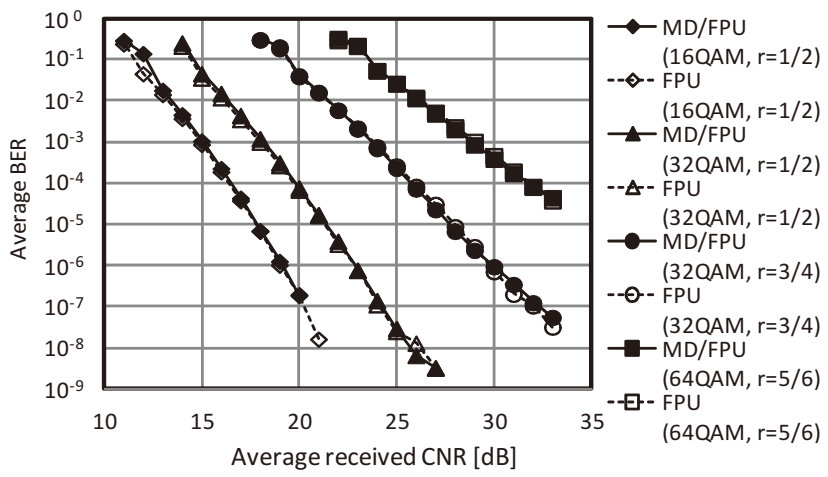

図 132 波マルチパス環境におけるビット誤り率特性 Bit error rate performance in 2-path channel model.

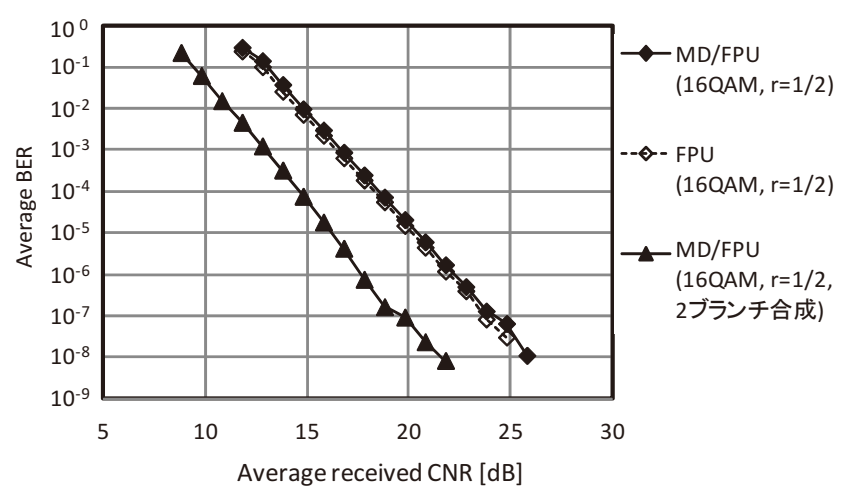

図 141 波レイリーフェージング環境におけるビット誤り率 特性

Bit error rate performance in 1-path Rayleigh channel model.

図 12 に, AWGN 環境に扔ける BER 特性の比較結果を示 す。外符号である RS（Reed-Solomon）符号の復号後に擬 似エラーフリーとなる $\mathrm{BER}=2 \times 10^{-4}$ において，16QAM （符号化率 $\mathrm{r}=1 / 2$ ) では, MD/FPU は FPU に対して 0.14 $\mathrm{dB}$ 劣化し, 64QAM $(\mathrm{r}=5 / 6)$ では, $0.35 \mathrm{~dB}$ 劣化した. 図 13 は，2 波マルチパス環境において BER 特性を比較した ものであり，いずれのケースでも $\mathrm{BER}=2 \times 10^{-4}$ において $\mathrm{MD} / \mathrm{FPU}$ はFPUに対して $0.2 \mathrm{~dB}$ 以下の劣化であった。ま た，図14は，1波レイリーフェージング環境に打ける BER 特性の比較結果であり, 本チャネルモデルでは, $\mathrm{MD} / \mathrm{FPU}$ は FPU に対して $0.2 \mathrm{~dB}$ の劣化であった. MD/FPUの 2 ブランチ合成の BER 特性も図 14 に併せて示す. 1 ブラ ンチ受信の $\mathrm{MD} / \mathrm{FPU}$ と比較して, $\mathrm{BER}=2 \times 10^{-4}$ におい て約 $4 \mathrm{~dB}$ のダイバーシテイ利得が得られていることがわ かる.

以上より，マクロダイバーシティ受信装置を経由するこ とで生じる受信特性の劣化は充分小さく, 2.4 節の固定小 数点設計は妥当であり, 充分なビット精度で実装できてい ることを確認した。

\section{3. 中継番組での運用}

3.1 RoF システム

本節では，マクロダイバーシティ受信装置に入力する各 
基地局の受信信号をスイッチングセンターに伝送するため の周辺設備として新たに試作した RoF システムについて説 明する。受信したSHF 带の RF（Radio Frequency）信号 を光回線で低損失に長距離伝送する場合, 高速な変調が可 能であるが高価な外部変調方式 14)15) の光変調器を使用す る必要がある。また，広いダイナミックレンジをもつ受信 信号に対し，信号劣化を抑えながら伝送するためには，高 性能な SHF 帯の AGC (Automatic Gain Control) 増幅 器などを用いて, 一定の電気信号レベルで光信号に変換す る必要があり, コストや運用面で課題がある，基地局側で 受信した RF 信号を, 取扱いが容易な IF 信号に周波数変換 することで, 小型かつ廉価な直接変調方式 ${ }^{16) 17)}$ の光変調 器を利用して, 低損失で長距離伝送することが可能となる.

以上の理由から，本システムでは，受信した RF 信号を IF 信号に周波数変換する小型受信高周波部を基地局側に設 置し，IF 信号を光信号に変換してスイッチングセンターに 伝送する構成とした。 図 15 (左) に試作した小型受信高周 波部の外観を示す。本高周波部は，6〜7 GHz 帯の RF 信 号を中心周波数が $130 \mathrm{MHz}$ の IF 信号に変換して, $0 \mathrm{dBm}$ で出力する. 消費電力は $8 \mathrm{~W}$ 程度であり, 電源のない場所 で長時間バッテリー運用することが可能である。一方, 図 15 (右) に, 市販されている直接変調方式の光変調器を用 いて試作した IF 带 5 波 WDM 伝送装置の外観を示す. 本 装置は, 電気/光変換器 $(\mathrm{E} / \mathrm{O})$ を利用して複数の IF 信号 を光信号に変換し, 光波長多重により 1 系統の光回線で伝 送する装置である。最大で 5 系統の信号を $1510 \mathrm{~nm} \sim 1590$ $\mathrm{nm}$ の複数の波長の光信号に変換して，1本の光ファイバ に多重して伝送することが可能である. 光回線を増設せず, 一つの基地局に複数の受信アンテナを設置できるため, 受 信システム構築の自由度を高めることができる。 また，本 装置の光信号の入出力コネクタは, SC 型または光カメラ コネクタに対応して扮り, 光カメラコネクタを使用する場 合は, $\mathrm{O} / \mathrm{E}$ 側から $\mathrm{DC}-12 \mathrm{~V}$ の電源を $\mathrm{E} / \mathrm{O}$ 側に供給するこ とも可能である.

\section{2 京都駅伝中継番組での運用}

本受信システムを実際の京都駅伝中継番組において，カ メラバイク映像の地上受信システムとして使用した. 図 16 に，本システムによる地上受信を想定する駅伝コースを示 す。地上受信エリアは, 図中の西京極陸上競技場（地点 $\mathrm{P}$ ) から五条通りと西大路通りを経て, 金閣寺を過ぎた千本北 大路付近（地点 Q）までの地上受信エリア1（往復 $14 \mathrm{~km}$ ) と, 白川通りの北白川別当町付近 (地点 $\mathrm{R}$ ) から花園橋付 近（地点 $\mathrm{S}$ ）までの地上受信エリア 2 (往復 $6 \mathrm{~km}$ ) である. 地上受信エリア1の受信基地局は 4 か所 $(\mathrm{A}, \mathrm{B}, \mathrm{C}, \mathrm{D})$, 設 置した受信アンテナは 8 本 (A1, B1, B2, B3, B4, C1, D1, $\mathrm{D} 2$ ），地上受信エリア 2 の受信基地局は 4 か所（E, F, G, $\mathrm{H})$ ，設置した受信アンテナは 5 本（E1, F1, G1, G2, H1) である. 受信アンテナは利得 $18 \mathrm{dBi}$ の電磁ホーン, $26 \mathrm{dBi}$ や $29 \mathrm{dBi}$ のパラボラアンテナなどを建物屋上や電柱に固定
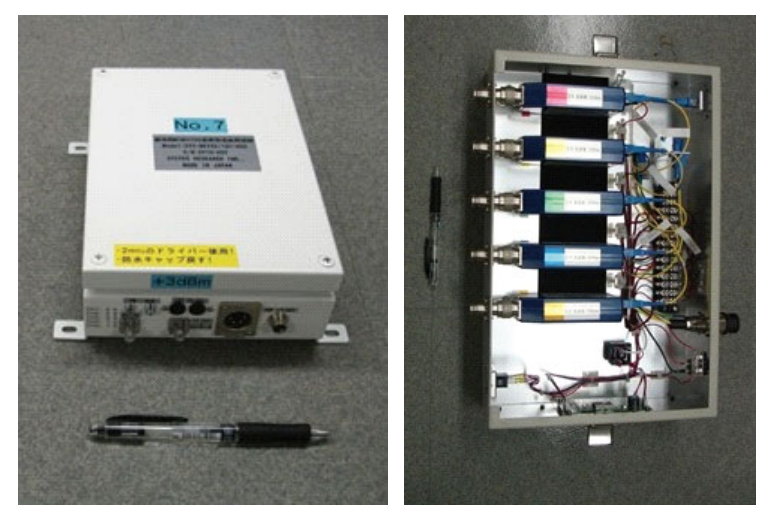

図 15 小型受信高周波部（左）と IF 带 5 波 WDM 伝送装置 (右)

Compact RF receiver unit (left) and IF-band five wavelength division multiplexing equipment (right]).

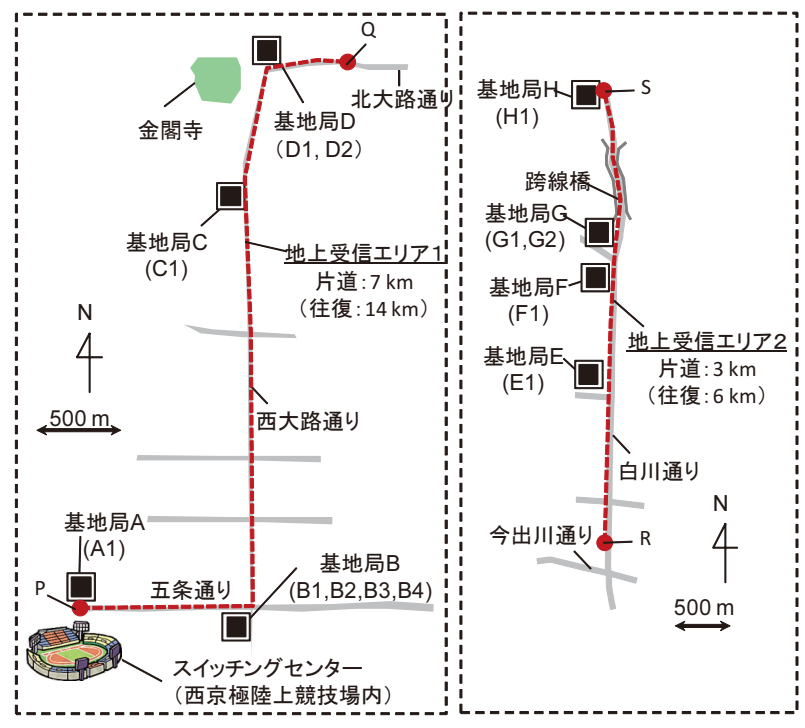

図 16 京都駅伝中継番組に扔ける受信基地局配置 Deployment of receive base stations in Kyoto Ekiden relay broadcast program.

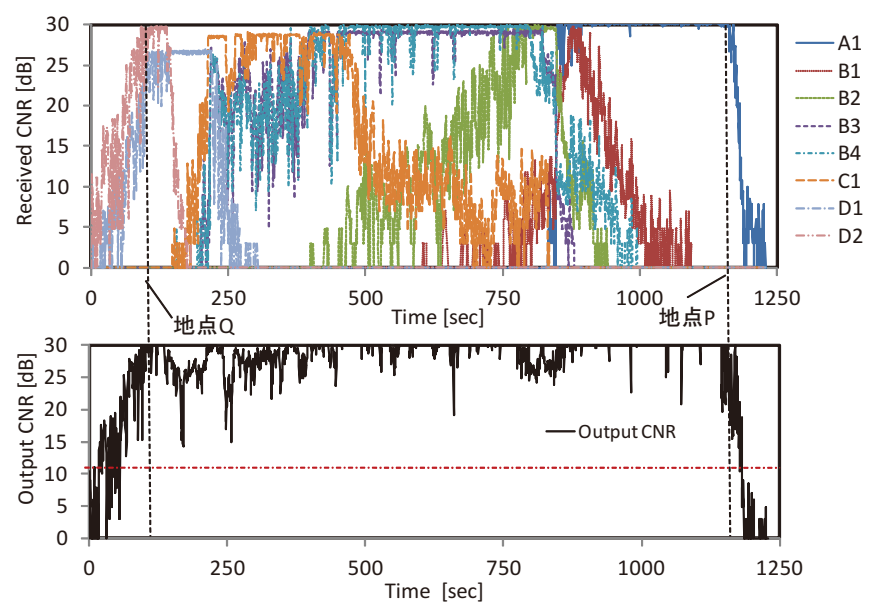

図 17 地上受信エリア1 (復路) の受信結果 Reception performance in terrestrial reception area 1 (the second half of the course).

して設置した。一方，送信信号は 2 分配され，バイクの進 行方向前方と後方それぞれに向けた利得 $15 \mathrm{dBi}$ のつの 電磁ホーンアンテナからそれぞれ $100 \mathrm{~mW}$ で出力された. 



図 18 地上受信エリア 2 (往路) の受信結果

Reception performance in terrestrial reception area 2 (the first half of the course).

IF 信号を同軸ケーブルで伝送した基地局 $\mathrm{A}$ を除き，各基 地局の受信信号は 3.1 節で述べた RoF システムを用いて 光回線でスイッチングセンターに集められた。図 17 に高 校駅伝 (男子) の本番時における地上受信エリア 1 (復路) の各受信 CNR と出力 CNR を, 図 18 に地上受信エリア 2 (往路) の各受信 CNR と出力 CNR の変動を経過時間に対 して示す. 図 17 より, 地上受信エリア 1 では, 受信 CNR が低下し始める前から他の基地局でも受信できるように置 局されており，信号合成後の出力 CNR も映像が途切れる ことなく伝送できる目安である $10 \mathrm{~dB}$ より充分高い值で, おおむね安定していることが確認できる。一方，図 18 よ り，地上受信エリア 2 では，G1 から G2，あるいは G2 か ら $\mathrm{H} 1$ など, 受信レベル低下後に次の基地局で受信を開始 するケースがあり，エリア境界でどの基地局も安定した受 信レベルを確保できない区間があることを確認できる。た だし，信号合成後の出力 CNR は $15 \mathrm{~dB}$ 以上確保できてい ることから，互いに離れた基地局間の合成ダイバーシティ 効果により, エリア境界でも安定した受信特性を得ること ができたものと考えられる。実際の中継番組でも，両コー スとも映像が途切れることはなく, 全コース $42.195 \mathrm{~km}$ の 約半分となる延べ $20 \mathrm{~km}$ を本システムによる $\mathrm{SHF}$ 帯の地 上受信でカバーすることに成功した。

\section{4. むすび}

基地局の区別なく最適な信号を選択して合成できるマク ロダイバーシティ受信装置の試作に関し, MMSE アルゴリ ズムをハードウェア実装するために必要な逆行列の演算方 法, 信号劣化を生じさせずビット精度を維持したまま固定 小数点演算を実現するための最適語長の決定方法や, 決定 した最適語長に基づき試作したマクロダイバーシティ受信 装置の基本特性を室内実験で評価した。また試作したマク ロダイバーシティ受信装置を実際の京都駅伝中継番組で使
用し，カメラバイクから SHF 帯の電波で送信されたハイ

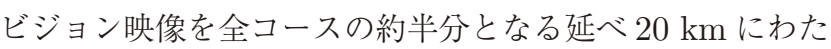
り途切れずに受信することに成功した。

\section{〔文献〕}

1）“テレビジョン放送番組素材伝送用可搬型 OFDM 方式デジタル無線伝 送システム”, 社団法人電波産業会，標準規格 ARIB STD-B33 1.1 版 (Nov. 2005)

2）池田:"八イビジョン素材伝送技術”, NHK 技研 R\&D, 73, pp.10-17 (May. 2002)

3）岡部, 池田, 渋谷: “QAM-OFDM 方式を用いた $800 \mathrm{MHz}$ 帯ハイビジョ ンデジタル FPU の開発”，2001 年映情学年次大，20-8, pp.298-299 (2001)

4）神崎, 花田, 大谷, 上原: “ロードレース中継に打けるシームレス伝搬ス イッチャーの開発”, 映情学技報, 28,33, pp.21-24（2004）

5) K. Mitsuyama, T. Ikeda and T. Ohtsuki : "Development of MMSE macro-diversity receiver with delay difference correction technique", IEEE GLOBECOM, (Dec. 2011)

6) S. Mukherjee and D. Avidor: "Effect of microdiversity and correlated macrodiversity on outages in a cellular system", IEEE Trans. Wireless Commun., 2, 1, pp.50-58 (Jan. 2003)

7) P. M. Shankar: "Macrodiversity and microdiversity in correlated shadowed fading channels", IEEE Trans. Veh. Technol., 58, 2, pp.727-732 (Feb. 2009)

8) K. Mitsuyama, T. Ikeda and T. Ohtsuki : "Hardware implementation of proposed antenna selection algorithm and its performance evaluation using received signals in field experiment", IEEE VTC2012-FALL, to be published (Sep. 2012)

9）菊間： “アレーアンテナによる適応信号処理”，科学技術出版 (1998)

10）竹内, 木村, 濱住, 渋谷: “ISDB-T 用アダプティブアレーの開発- MMSE アダプティブアレーの放送波中継への応用一”, 映情学誌, 60,1, pp.66-75 (2006)

11) T. Ohgane, T. Nishimura, and Y. Ogawa: "Applications of space division multiplexing and those performance in a MIMO channel", IEICE Trans. Commun., E88-B, 5, pp.1843-1851 (May. 2005)

12）和田：“Verilog-HDL を用いた $4 \times 4$ 逆行列演算回路の開発”, 信学技報, CPSY2004-45, pp.77-81 (Dec. 2004)

13）藤野, 阿倍: “歴史文化的に見た関-Sarrus の公式について”，情処学研 究報告, 2000, 8, pp.57-64 (Jan. 2000)

14) C. H. Cox, G. E. Betts, and L. M. Johnson: "An analytic and experimental comparison of direct and external modulation in analogue fiber-optic links", IEEE Trans., 38, 5, pp.501-509 (May 1990)

15) D. W. Dolfi and T. R. Ranganath: "50 GHz velocity matched, broad wavelength $\mathrm{LiNbO}_{3}$ modulator with multimode active section", Electron. Lett., 28, 13, pp.1197-1198 (Jun. 1992)

16）上林，貴堂：“光エレクトロニクス”，森北出版（1992）

17) K. Sato, S. Kuwahara, Y. Miyamoto, and N. Shimizu: "40 Gbit/s direct modulation of distributed feedback laser for very-shortreach optical links", Electron. Lett., 38, 15, pp.816-817 (Jul. 2002)

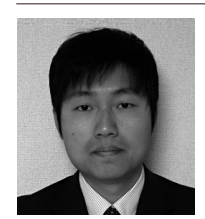

みつやま 㠰ざひこ 1999 年, 京都大学大学院工学研究科 修士課程修了. 同年, NHK に入局. 放送技術局を経て, 2002 年より, 放送技術研究所に勤務. 番組中継用無線伝 送技術の研究に従事。現在，放送技術研究所（放送ネッ トワーク研究部) 専任研究員. 慶應義塾大学理工学研究 科後期博士課程に在学中. 学生会員.

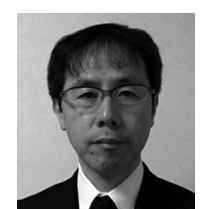

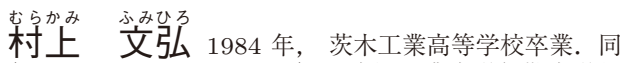
年, NHK に入局. 1987 年, 大阪工業大学短期大学部 卒業。大阪放送局，神戸放送局を経て，2006 年より，大 阪放送局に勤務。ロードレースなどの中継番組制作に従 事. 現在, 大阪放送局 (技術部) チーフエンジニア.

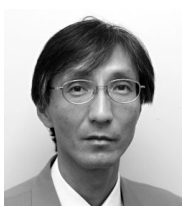

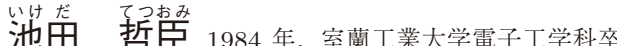
業. 同年, NHK に入局. 旭川放送局を経て，1989 年よ り，放送技術研究所に勤務. 地上デジタル放送伝送方式, 番組中継用伝送方式の研究に従事. 現在，放送技術研究 所（放送ネットワーク研究部）主任研究員. 正会員 